\title{
IMPLEMENTASI KEAMANAN DATA MENGGUNAKAN ALGORITMA BLOWFISH PADA SISTEM INFORMASI KOPERASI RIAS
}

\author{
Susanto \\ Program Studi Teknik Informatika \\ STMIK MUSIRAWAS \\ Email: susanto@muralinggau.ac.id
}

\begin{abstract}
ABSTRAK
Database merupakan tempat penyimpanan data dan informasi yang harus dijaga keamanan dan kerahasiaannya. Untuk menjaga keamanan dan kerahasiaannya data yang di simpan di dalam database menggunakan kriptografi. Sistem informasi koperasi RIAS merupakan sistem yang memproses data anggota, simpanan dan peminjaman sehingga data yang tersimpan harus terjamin kerahasiaannya. Guna menjaga keamanan data pada sistem informasi koperasi RIAS, menggunakan algoritma kriptografi simetris blowfish. Algoritma kriptografi simetris blowfish merupakan algoritma modern kunci simetris berbentuk cipher blok. Kunci simetris yang digunakan untuk enkripsi dan dekripsi harus sama,sehinggauntuk mempermudah proses enkripsi dan dekripsi pada database yang jumlah datanya sangat banyak maka kunci public yang digunakan pada sistem informasi koperasi RIAS dimasukkan kedalam source code. Sistem informasi koperasi rias dibangun menggunakan bahasa pemrograman php dan database menggunakan MySQL.Berdasarkan hasil, data yang di inputkan pada sistem informasi koperasi RIAS pada database berhasil di enkripsi sehingga tidak dapat dibaca dan dimengerti artinya, selanjutnya data yang sebenarnya dapat ditampilkan pada menu tampil data ataupun laporan.
\end{abstract}

Kata kunci: database, algoritma blowfish, sistem informasi.

\section{ABSTRACT}

Database is a place to save data and information that have to be guarded security and secrecy. To keep security and secrecy data which is saved in database should be using cryptography. RIAS cooperative of information systems is a system which processes the data members, saving and loan so the data that stored to be guaranteed of secrecy. To keep a security data, it used symmentric cryptographic algorithms blowfish. Symmentric cryptographic algorithms blowfish is algorithms modern symmentric key shaped block chipher. The symmentrickey was used for encryption and description should be the same so that it could give easy processing for encryption and description on the database that the data was so full, thus the public key which's used at RIAS cooperative of information systemswas input at source code. RIAS cooperative of information systemswas constructed by PHP programming language and it's database by MYSQL.Based on the result, the data that's input in RIAS cooperative of information systems in database has succeed for encryption so the meaning can't be read and understood. Finally, the next real data can be showed in desktop or report.

Keywords: database, algorithm blowfish, information systems.

\section{PENDAHULUAN}

Database [10] merupakan tempat penyimpanan data dan informasi. Seluruh sistem menyimpan datanya di dalam database, sehingga isi data yang tersimpan harus dijaga keamanan dan kerahasiaannya. Untuk menjaga keamanan [5] database tersebut diperlukan sebuah metode, metode tersebut adalah kriptografi.

Kriptografi [2] merupakan teknik matematika untuk berurusan dengan keamanan informasi seperti kerahasiaan, keutuhan data dan otentifikasi. Algoritma kriptografi terbagi menjadi dua yaitu algoritma simetris dan algoritma asimetris [2]. Salah satu contoh algoritma simetris adalah blowfish. Algoritma kriptografi simetris blowfish [1] merupakan algoritma modern kunci simetris berbentuk cipher block. Kunci simetris yang digunakan untuk proses enkripsi dan dekripsi sama seperti yang terlihat pada gambar 1 . 

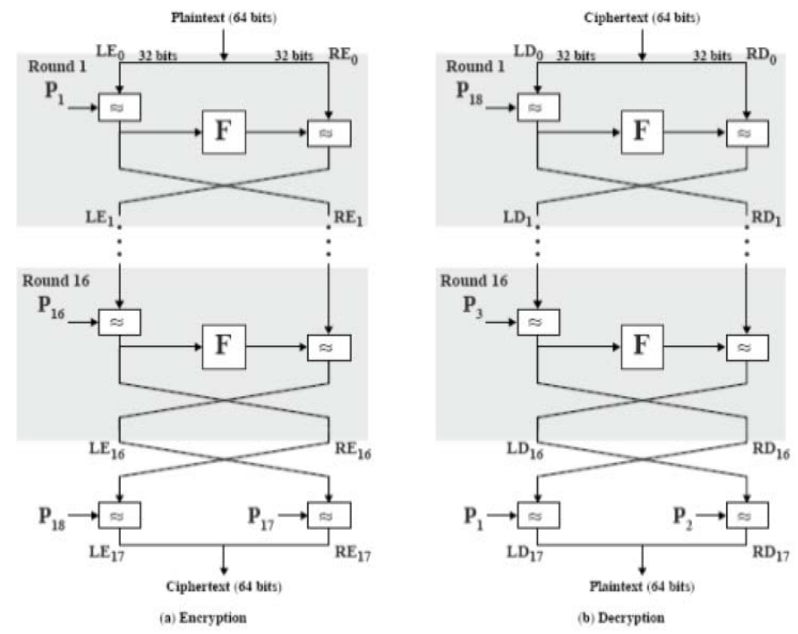

Gambar 1. Proses Enkripsi dan Dekripsi Blowfish

Sistem informasi [6] koperasi RIAS merupakan sistem yang memproses data anggota, simpanan, peminjaman dan angsuran yang datanya di simpan ke dalam database, sehingga data yang tersimpan di dalam database perlu dijamin keamanan dan kerahasiaannya. untuk mempermudah proses enkripsi dan dekripsi [3] pada sistem informasi koperasi [4] RIAS yang jumlah datanya sangat banyak dan kunci yang digunakan harus sama, maka kunci publik dimasukkan kedalam source code. Sistem informasi koperasi RIAS dibangun menggunakan bahasa pemrograman php dan database menggunakan MySql.

\section{METODOLOGI PENELITIAN}

Penelitian ini menggunakan model Prototyping [9]. Peneliti menggunakan metode ini dikarenakan didalam model ini peneliti dalam merancang sistem dan membuat sistem dilakukan secara bertahap. Sehingga dapat mengurangi tingkat kesalahan. Adapun tahapan yang dilakukan dalam penelitian ini menggunakan prototyping [8] adalah sebagai berikut:

1) Peneliti menganalisis sistem dan keamanan sistem yang sedang berjalan. Analisa dilakukan dengan cara wawancara dengan pimpinan dan meninjau langsung sistem informasi koperasi yang sudah ada.

2) Peneliti mulai membangun sistem dan keamanannya. Sistem informasi dibangun menggunakan bahasa pemrograman PHP dan basis datanya menggunakan MySQL, serta menggunakan algoritma blowfish membangun keamanan datanya.

3) Peneliti dan pihak Koperasi RIAS menguji sistem yang sudah dibuat dan memberikan masukan terhadap sistem baru tersebut. Pengujian sistem ini menggunakan metode blackbox testing.

4) Jika sistem dan kemananannya sudah tepat maka siap di implementasikan.

\section{HASIL DAN PEMBAHASAN}

Implementasi keamanan data menggunakan algoritma blowfish pada sistem informasi koperasi RIAS yang merupakan hasil penelitian ini meliputi:

\subsection{Analisis Sistem}

Proses analisis sistem dimulai dengan menganalisa sistem informasi yang sudah ada. Proses analisis ini dilakukan dengan wawancara secara langsung dengan karyawan dan pimpinan Koperasi RIAS, setelah itu dilanjutkan dengan pengecekan langsung sistem yang lama dengan melihat isi data di dalam database.

\subsection{Membangun Sistem dan Keamanannya}

Proses membangun sistem dimulai dengan merancang sistem yang dibantu dengan diagram bantu menggunakan use casediagram dan class diagram, dilanjutkan dengan merancang database menggunakan MySQL yang digunakan untuk menyimpan data. Setelah selesai merancang sistem, dilanjutkan dengan merancang antar muka sistem informasi dan membuat algoritma blowfish. 
1) Use case diagram

Use case diagram berfungsiuntuk menggambarkan dan memodelkan serta mengorganisasi pada sistem sistem informasi koperasi RIAS, dimana pembuatan diagram ini terdiri dari 3 aktor yaitu admin, anggota dan manajer. Sehingga apa yang diperbuat oleh aktor tersebut pada sistem infomasi koperasi terlihat dengan jelas yang disajikan pada gambar 2 .

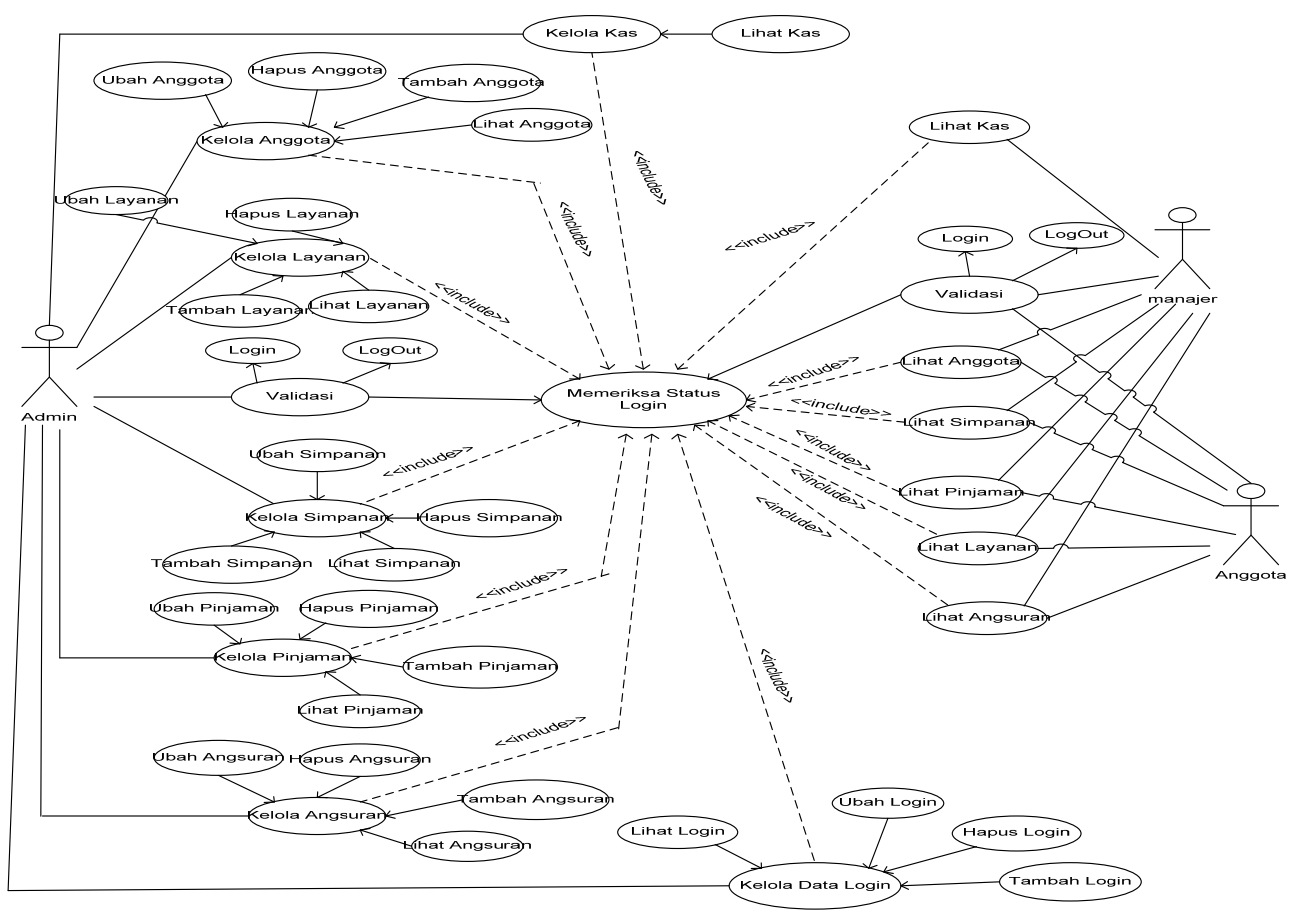

Gambar 2. Use Case Diagram

2) Class diagram

Class diagram berfungsi untuk menjelaskan hubungan antar class pada sistem informasi koperasi RIAS. Class diagramtersebut disajikan pada gambar 3. 


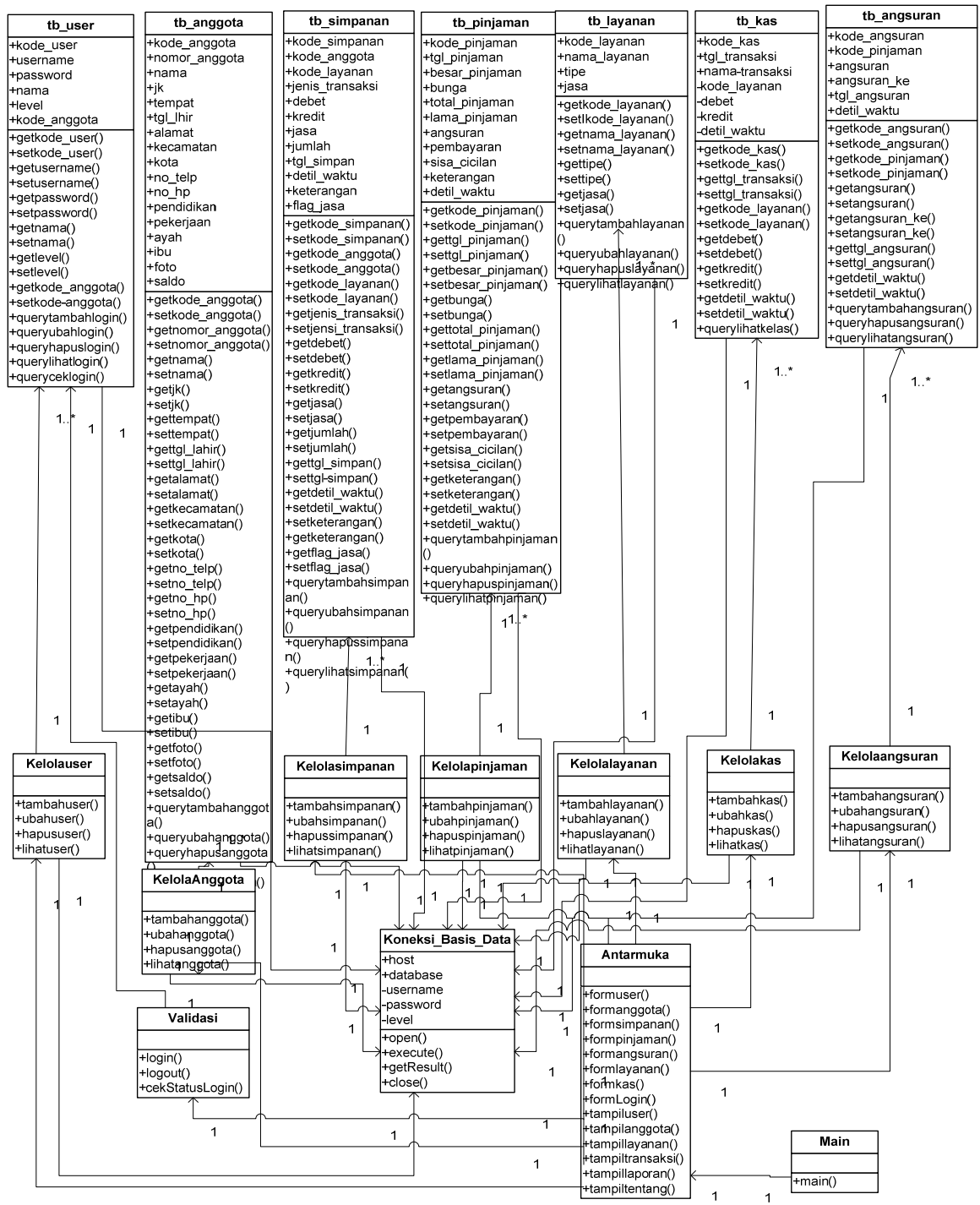

Gambar 3. Class Diagram

3) Database

Rancangan database yang dibuat antara lain
a. Tabel user
b. Tabel anggota
c. Tabel simpanan
d. Tabel pinjaman
e. Tabel angsuran
f. Tabel kas
g. Tabel layanan
$h$. Tabel pengaturan profil

4) Antar muka

Antarmuka pada sistem informasi koperasi terdiri dari level admin, level anggota dan level pimpinan. Rancangan antar muka yang akan dibuat antara lain :

a. Halaman login.

b. Halaman data anggota yang terdiri dari tampil data anggota, tambah data anggota, detail data anggota, ubah data anggota, hapus data anggota, cetak data anggota dan pencarian data anggota.

c. Halaman produk layanan yang terdiri dari tampil data produk layanan, tambah data produk layanan dan ubah data produk layanan. 
d. Halaman transaksi yang terdiri dari sub menu simpanan yaitu tampil data simpanan, detail simpanan, tambah data simpanan, pencarian data simpanan; sub menu pinjaman yaitu tambah data pinjamanan, detail data pinjaman, angsuran dan pencarian data pinjaman; sub menu kas yaitu tampil data kas.

e. Halaman data user yang terdiri dari tampil data user, tambah data user, ubah data user dan hapus data user.

f. Halaman pengaturan profil.

5) Algoritma Blowfish

Pada dasarnya, algoritma enkripsi blowfish membutuhkan 32 bit mikroprosesor pada tingkat satu byte untuk setiap 26 siklus clock. Blowfish berisi 16 putaran. Setiap putaran terdiri dari XOR operasi dan fungsi. Setiap putaran terdiri dari ekspansi kunci dan enkripsi data. Kunci ekspansi umumnya digunakan untuk menghasilkan isi dari satu array dan enkripsi data menggunakan 16 putaran feiestel metode jaringan. Gambar 1 menunjukkan algoritma bagaimana blowfish bekerja. teks dan kunci biasa adalah masukan dari algoritma. 64 bit plaintext diambil dibagi menjadi dua masing-masing 32 bit data dan di setiap putaran kunci yang diberikan diperluas dan disimpan dalam 18 array dan memberikan kunci 32 bit sebagai input dan XOR dengan data sebelumnya.

Kemudian, untuk $i=1$ sampai 14 :

$\mathrm{xL}=\mathrm{xL}$ XOR Pi

$\mathrm{xR}=\mathrm{F}(\mathrm{xL}) \mathrm{XOR} x \mathrm{x}$

Swap xL dan $x R$

Setelah putaran keenam belas, pertukaran $\mathrm{xL}$ dan $\mathrm{xR}$ lagi untuk mengembalikan kembali keswap terakhir. Kemudian, $x R=x R$ XOR P15 dan $x L=x L$ XOR P16. Akhirnya, bergabung kembali XL dan xR untuk mendapatkan ciphertext.

Sehingga jika algoritma blowfish dituangkan kedalam source code PHP menjadi sebagai berikut :

$<$ ?php

class Cipher \{

private \$algo;

private \$mode;

private \$source;

private $\$$ iv = null;

private \$key = null;

public function _construct(\$algo $=$ MCRYPT_BLOWFISH, \$mode $=$

MCRYPT_MODE_CBC, \$source = MCRYPT_RAND) \{

\$this->algo = \$algo;

\$this $->$ mode $=$ \$mode;

\$this->source = \$source;

if (is_null(\$this->algo) || (strlen $(\$$ this->algo $)=0)$ \{

\}

\$this->algo = MCRYPT_BLOWFISH;

if (is_null(\$this->mode) || (strlen $(\$$ this $->$ mode $)==\odot))\{$

\}

\$this $->$ mode $=$ MCRYPT_MODE_CBC;

\}

public function encrypt (\$data, \$key = null, \$iv = null $)\{$

\$key $=(\operatorname{strlen}(\$$ key $)==0)$ ? \$key = null : \$key;

\$this->setKey (\$key);

\$this->setIV(\$iv)

\$this->iv);

\$out = mcrypt_encrypt (\$this->algo, \$this->key, \$data, \$this->mode,

\}

return base64_encode(\$out);

public function decrypt (\$data, \$key = null, \$iv = null) \{

\$key $=(\operatorname{strlen}(\$$ key $)==0)$ ? \$key = null : \$key;

\$this->setKey (\$key);

\$this->setIV(\$iv);

\$data $=$ base64_decode $(\$$ data $) ;$

\$this->iv);

\$out = mcrypt_decrypt (\$this->algo, \$this->key, \$data, \$this->mode,

\}

return $\operatorname{trim}($ \$out);

public function getIV() \{

return base64_encode( $\$$ this->iv);

\}

private function setIV(\$iv) \{ 


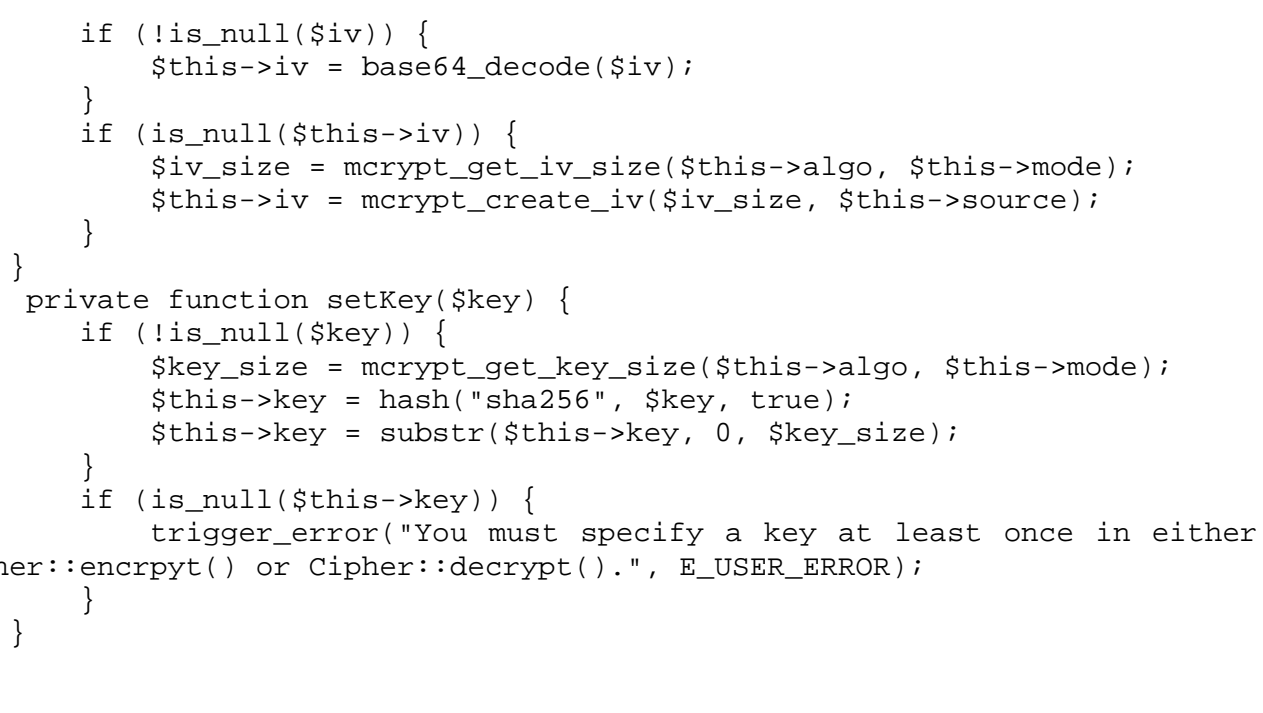

\subsection{Implementasi dan Pengujian Keamanan Data pada Sistem}

Implementasi bertujuan untuk mengkonfirmasi hasil perancangan sistem informasi yang telah dilakukan, sehingga pengguna dapat memberi masukanpada pengembangan sistem informasi. implementasisistem informasi koperasi RIAS dilakukan dengan bahasa pemrograman PHP dan MySQL sebagai Database Management System.Pengujian keamanan data pada sistem informasi koperasi RIAS dapat terlihat pada gambar 4 sampai dengan gambar 22, data yang tersimpan didalam database yang terenkripsi dan terdekripsi ke bentuk semula terlihat pada form tampilan data.

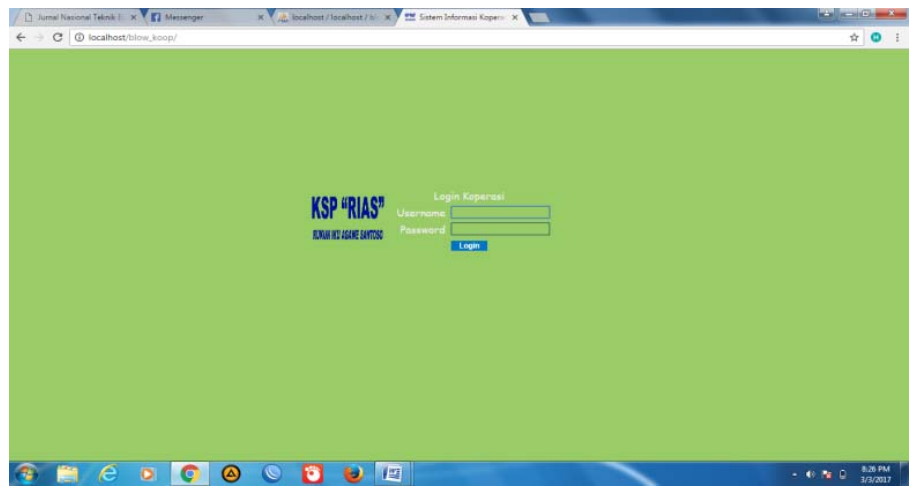

Gambar 4. Form Login

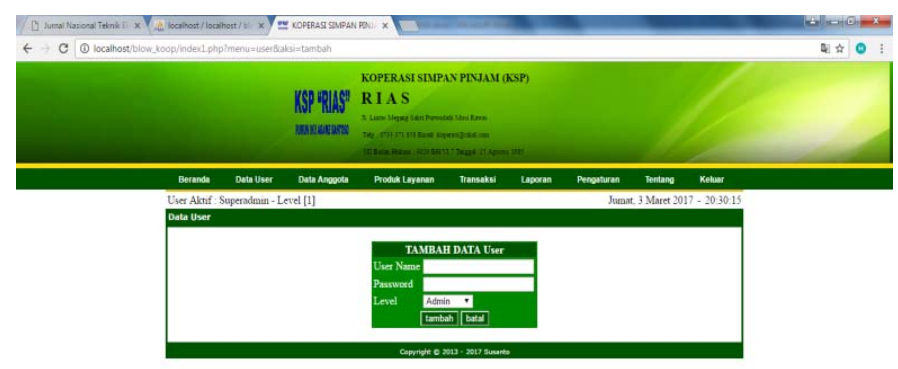

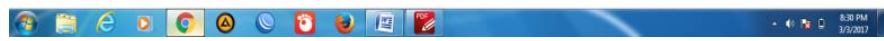

Gambar 5. Form Tambah Data User 
Halaman tambah data userini digunakan untuk memasukkan data user yang akan menggunakan sistem informasi koperasi RIAS.

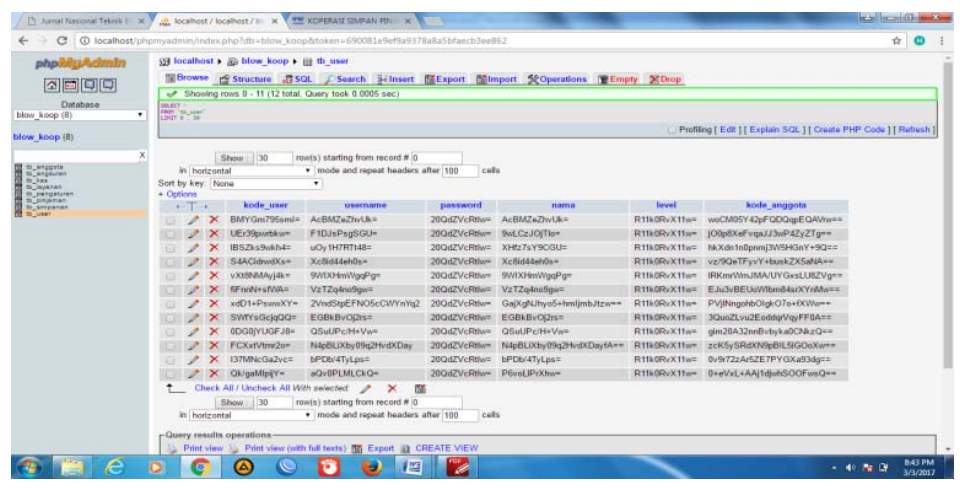

Gambar 6. Database Data User

Data yang telah di masukan pada form tambah data anggota akan tersimpan pada database data user. Data yang tersimpan tersebut terenkripsi.

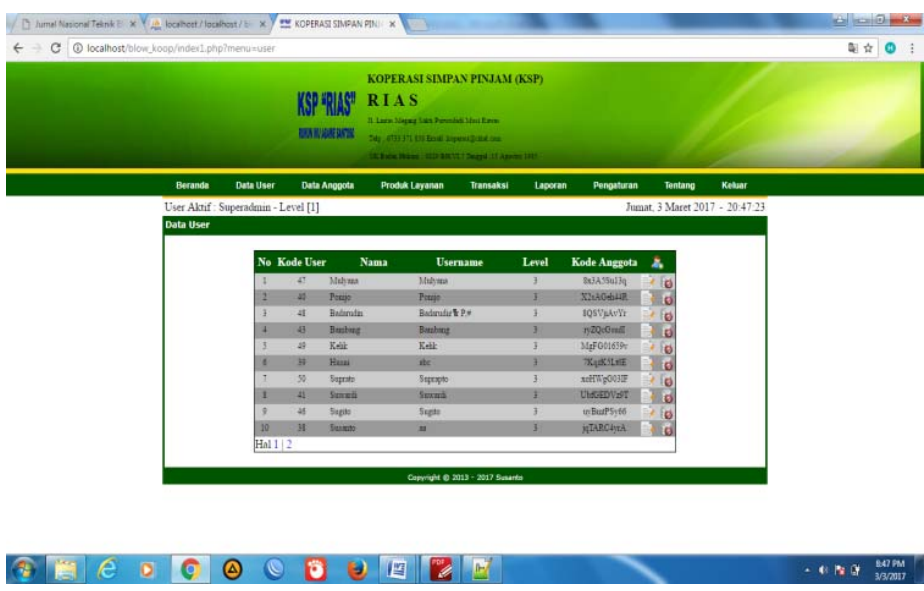

Gambar 7. Tampilan Data User

Pada halaman tampilan data userini menampilkan seluruh informasi data user, informasi data user yang di tampilkan telah terdekripsi ke bentuk aslinya sehinnga dapat dimengerti isinya.

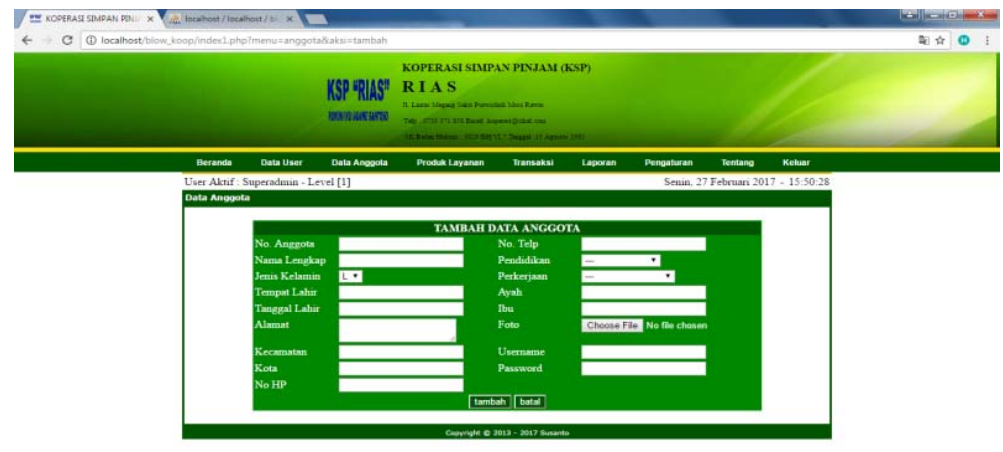

की

Gambar 8 Form Tambah Data Anggota 
Halaman tambah data anggota ini digunakan untuk memasukkan data diri setiap anggota koperasi RIAS.

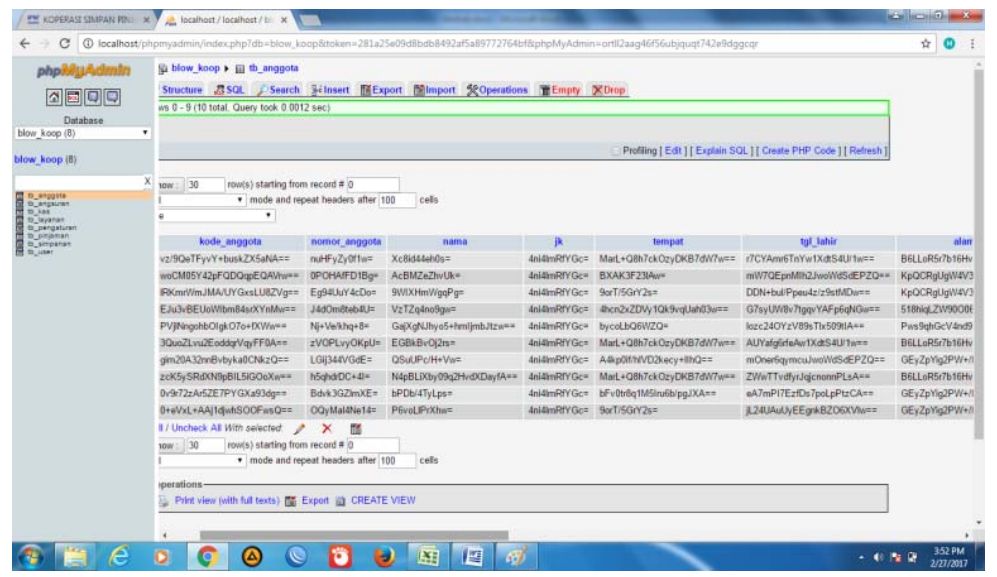

\section{Gambar 9. Database Data Anggota}

Data yang telah di masukkan pada formtambah data anggota akan tersimpan pada database data anggota. Data yang tersimpan tersebut terenkripsi.
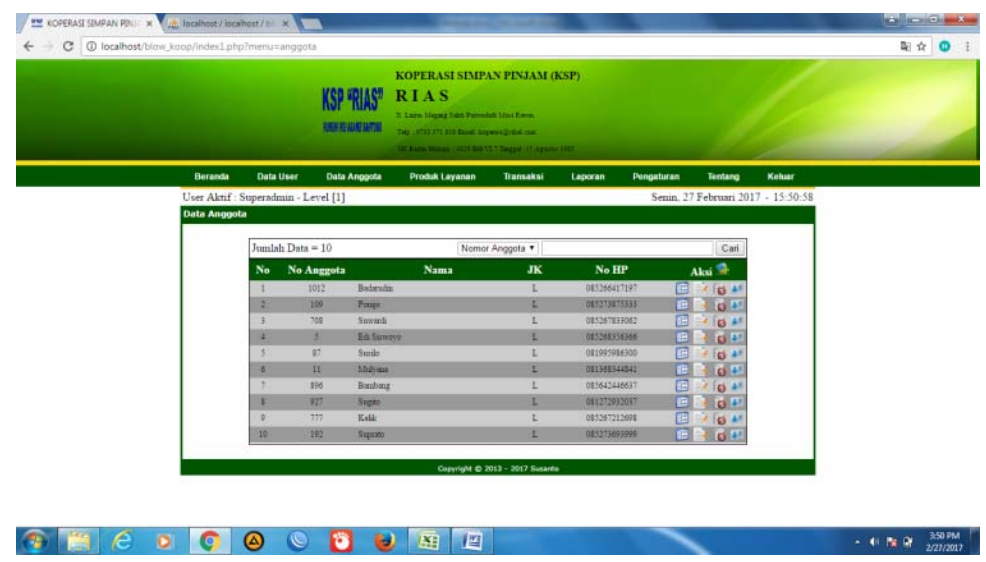

\section{Gambar 10. Tampilan Data Anggota}

Pada halaman tampilan data anggota ini menampilkan seluruh informasi data anggota, informasi data anggota yang di tampilkan telah terdekripsi ke bentuk aslinya sehinnga dapat dimengerti isinya.

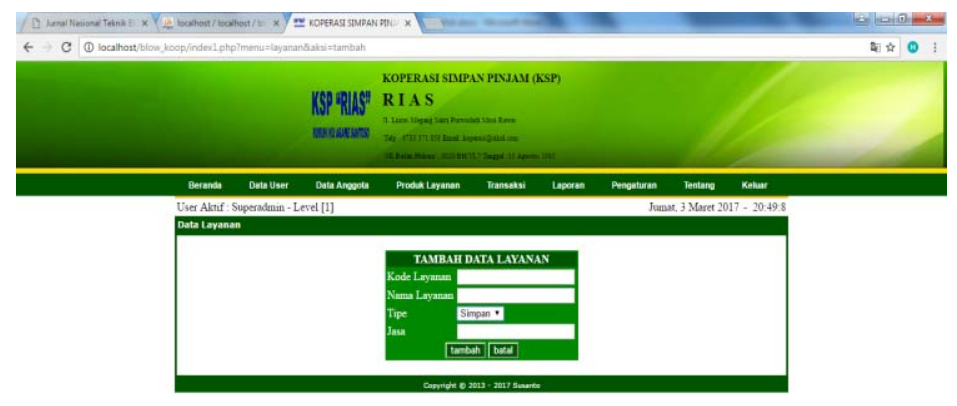

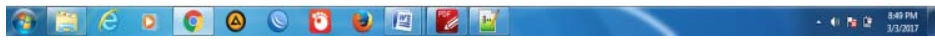

Gambar 11. Form Tambah Data Layanan 
Halaman tambah data layanan ini digunakan untuk memasukkan data layanan yang terdapat pada sistem informasi koperasi RIAS.

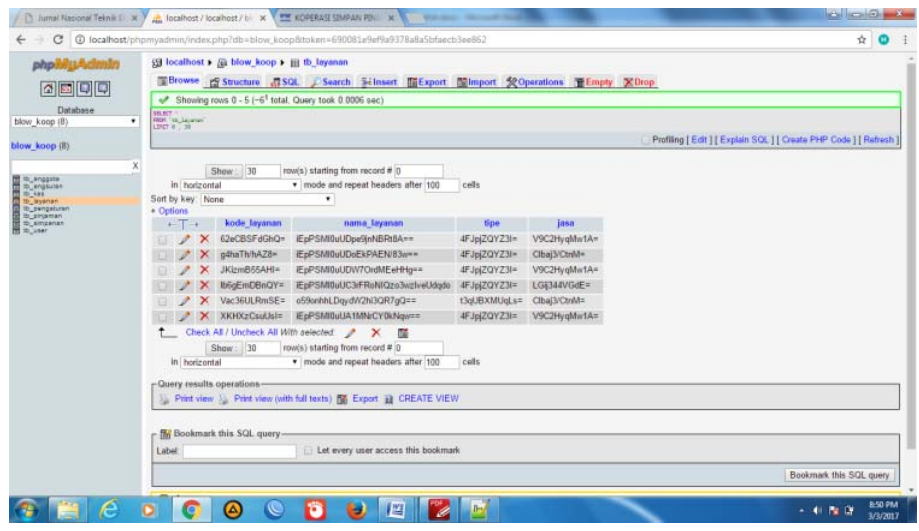

Gambar 12. Database Data Anggota

Data yang telah di masukkan pada formtambah data layanan akan tersimpan pada database data layanan. Data yang tersimpan tersebut terenkripsi.
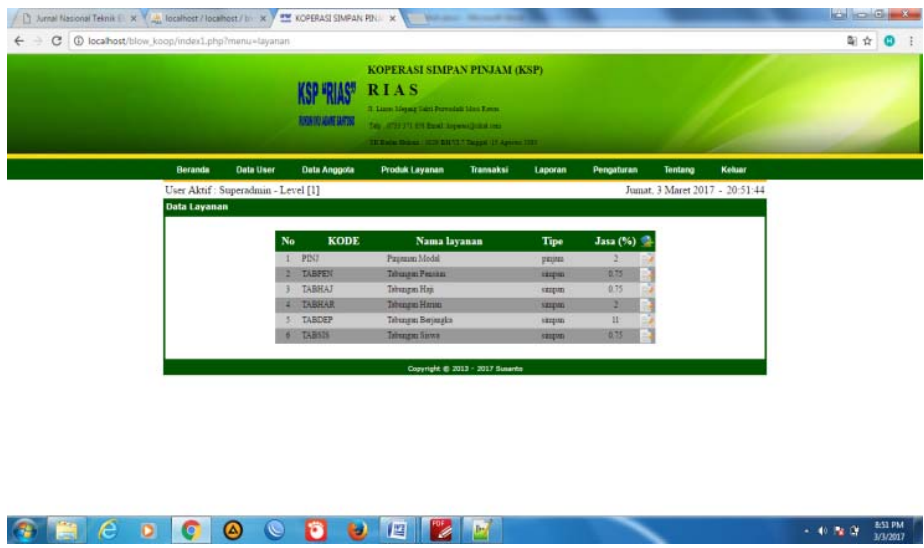

Gambar 13. Tampilan Data Layanan

Pada halaman tampilan data layanan ini menampilkan seluruh informasi data layanan, informasi data layanan yang di tampilkan telah terdekripsi ke bentuk aslinya sehinnga dapat dimengerti isinya.

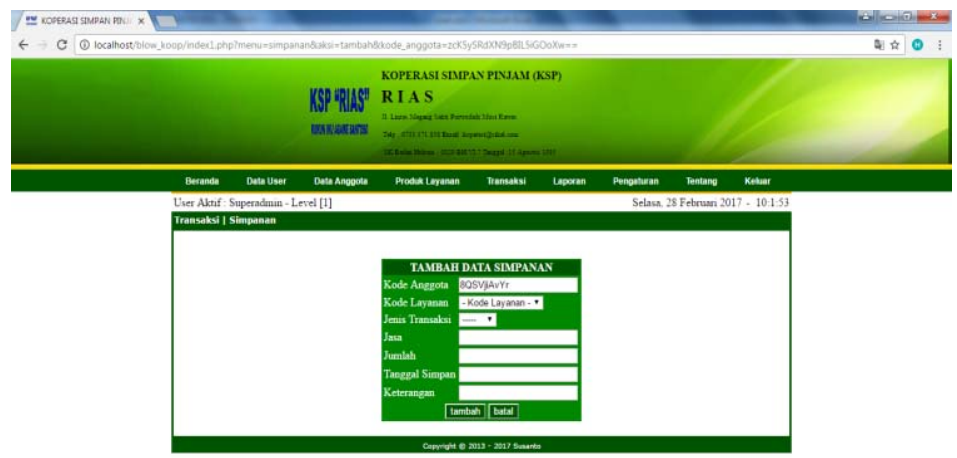

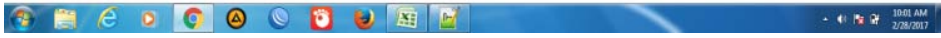

Gambar 14. Form Tambah Data Anggota 
Halaman tambah data simpanan anggota ini digunakan untuk memasukkan data simpanan anggota koperasi RIAS.

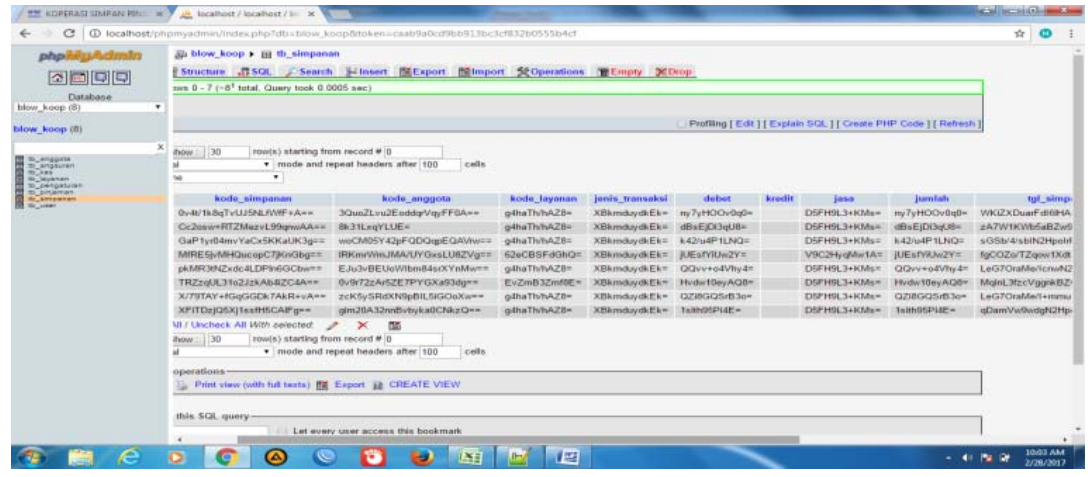

Gambar 15. Database Data Simpanan

Data yang telah di masukkan pada form tambah data simpanan akan tersimpan pada database simpanan anggota. Data yang tersimpan tersebut terenkripsi.
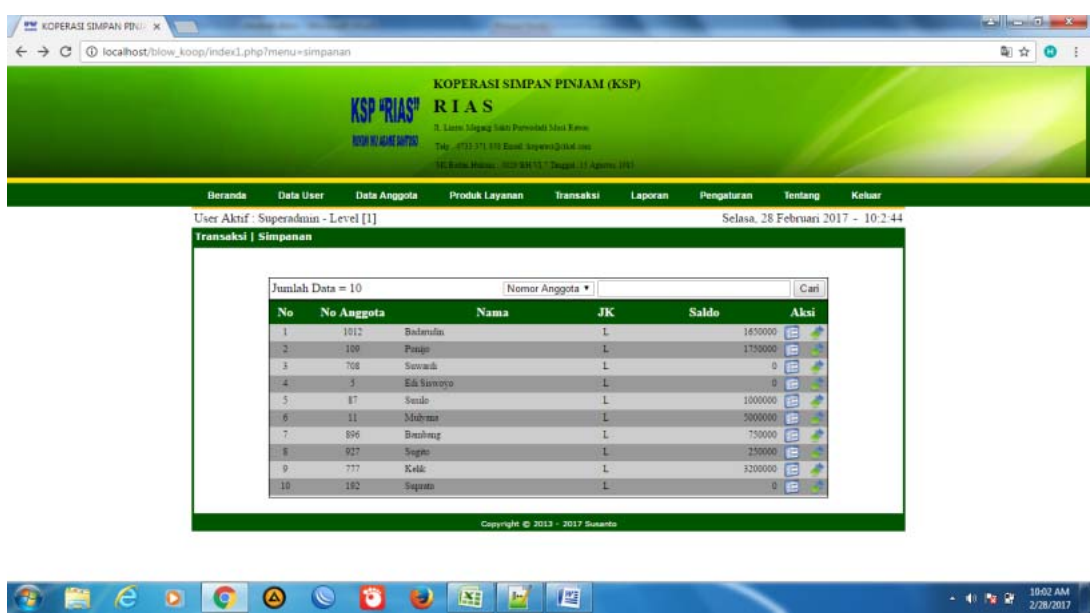

\section{Gambar 16. Tampilan Data Simpanan Anggota}

Pada halaman tampilan data simpanan anggota ini menampilkan seluruh informasi data simpanan anggota, informasi data simpanan anggota yang di tampilkan telah terdekripsi ke bentuk aslinya sehinnga dapat dimengerti isinya.
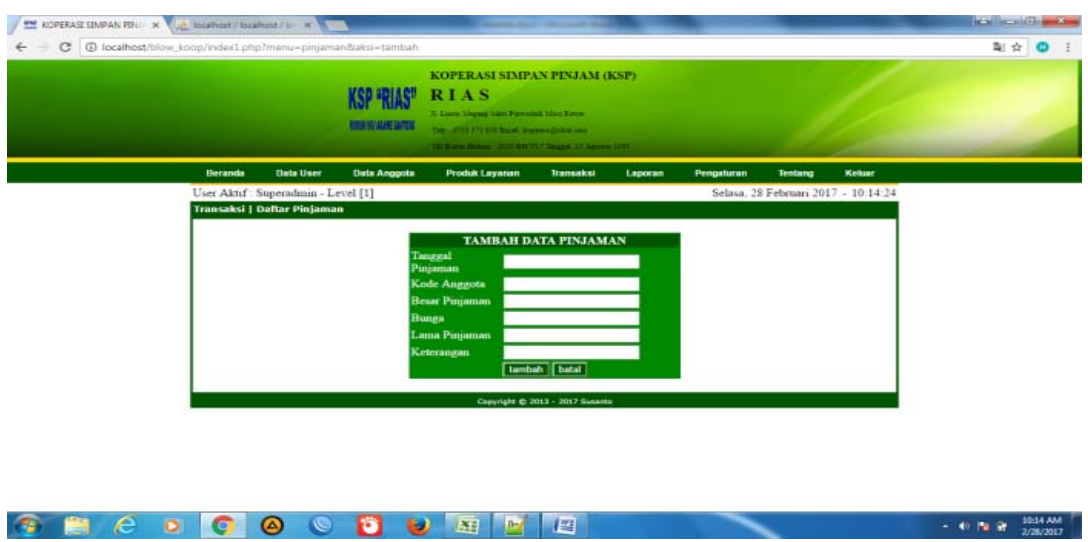

Gambar 17. Form Tambah Data Pinjaman Anggota 
Halaman tambah data pinjaman anggota ini digunakan untuk memasukkan data pinjaman anggota koperasi RIAS.

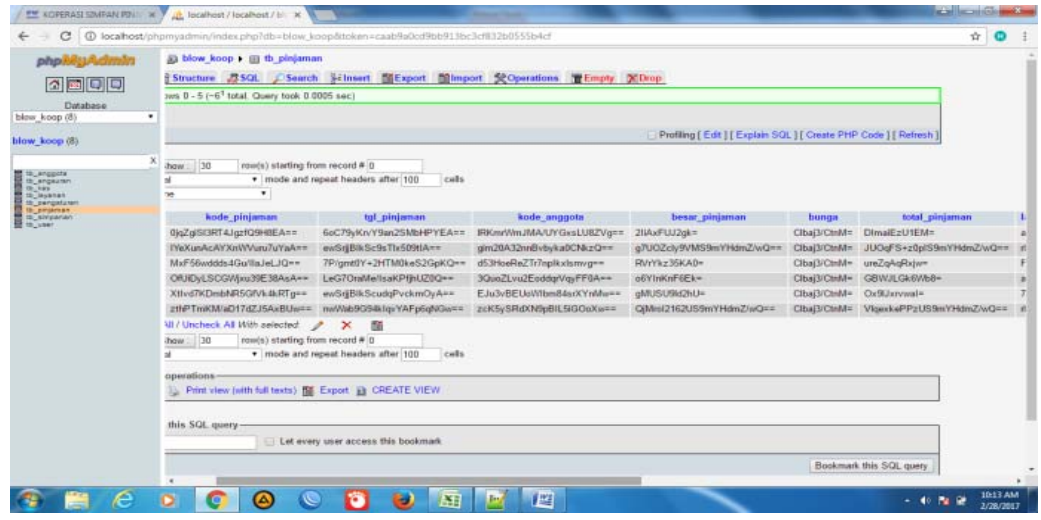

Gambar 18. Database Data Pinjaman Anggota

Data yang telah di dimasukkan pada formtambah data pinjaman anggota akan tersimpan pada database data pinjaman anggota. Data yang tersimpan tersebut terenkripsi.
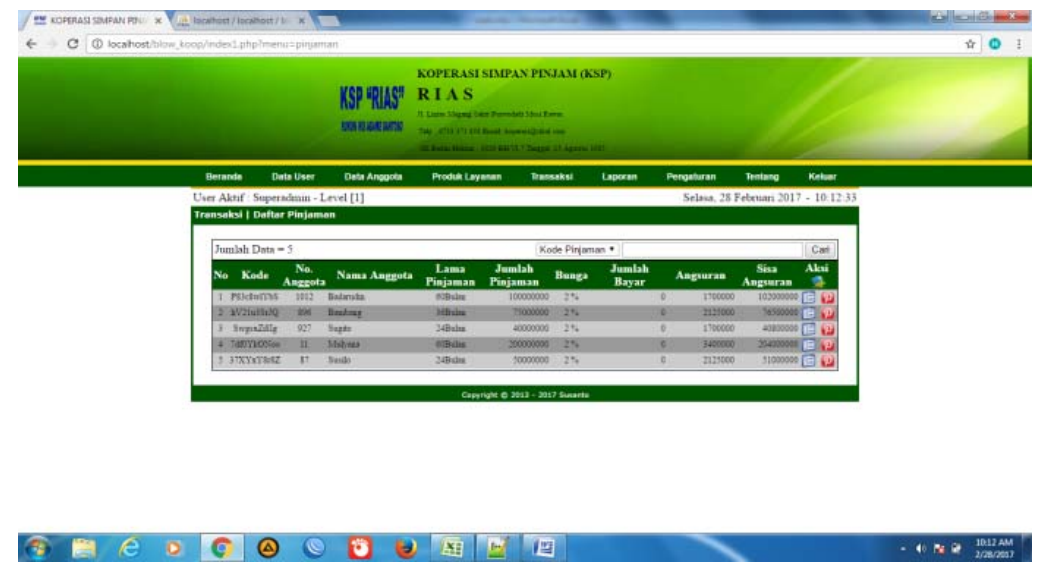

\section{Gambar 19. Tampilan Data Pinjaman Anggota}

Pada halaman tampilan data pinjaman anggota ini menampilkan seluruh informasi data pinjaman anggota, informasi data pinjaman anggota yang di tampilkan telah terdekripsi ke bentuk aslinya sehinnga dapat dimengerti isinya.

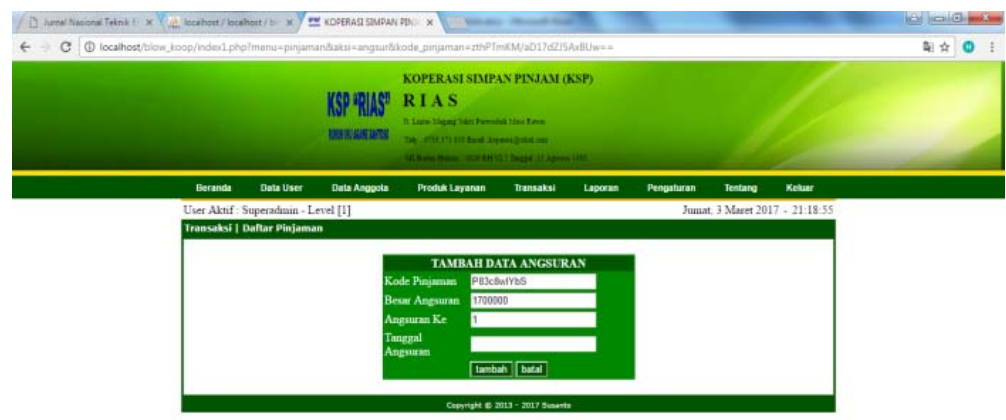

(9)

Gambar 20. Form Tambah Data Angsuran Pinjaman 
Halaman tambah data angsuran pinjaman anggota ini digunakan untuk memasukkan data angsuran pinjaman anggota koperasi RIAS.

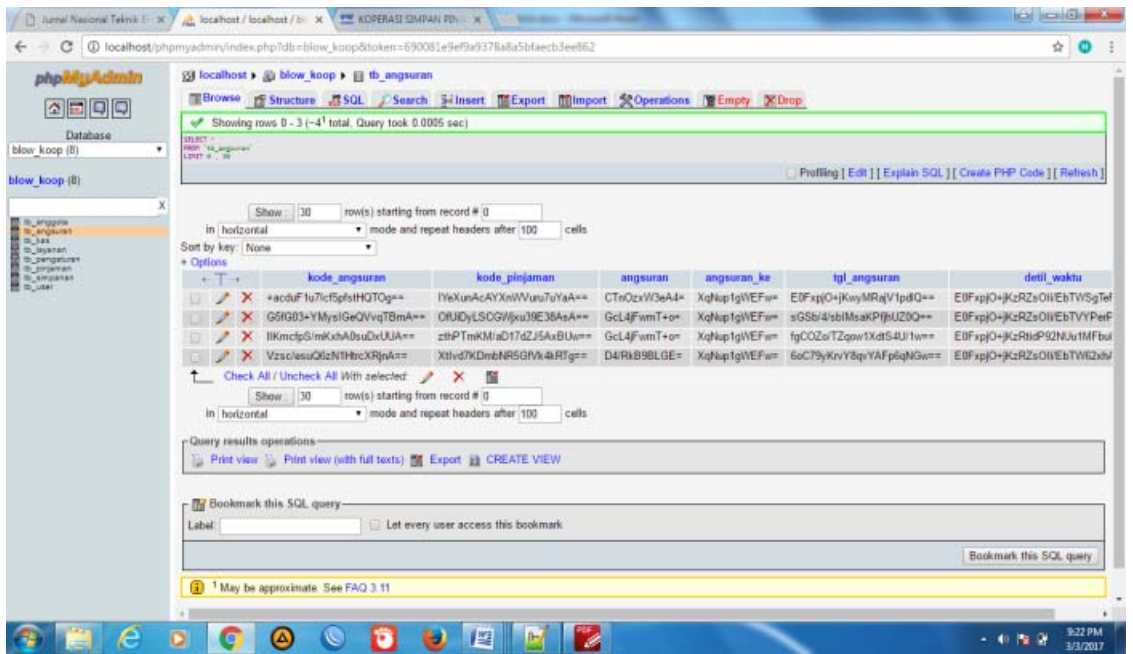

Gambar 21. Database Data Angsuran Pinjaman

Data yang telah di dimasukkan pada formtambah data angsuran pinjaman anggota akan tersimpan pada database data angsuran pinjaman anggota. Data yang tersimpan tersebut terenkripsi.

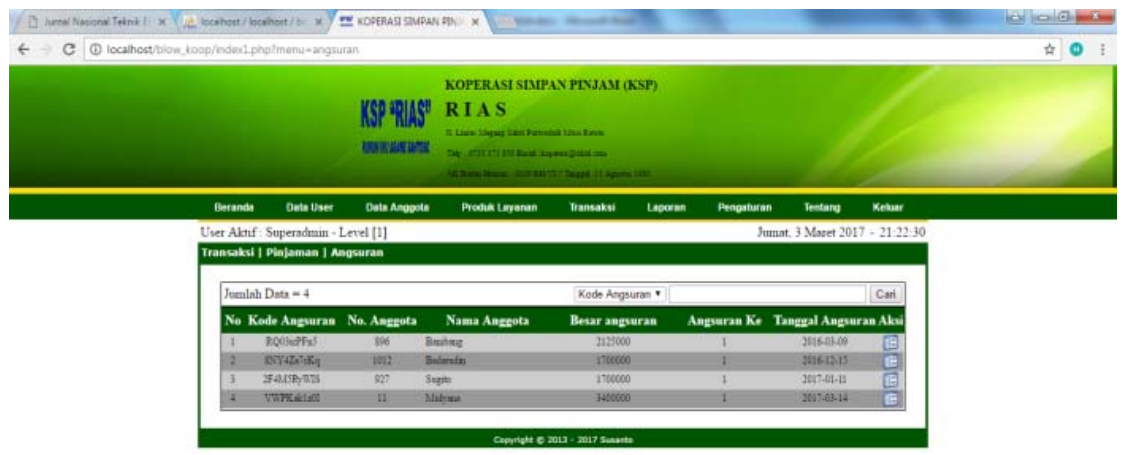

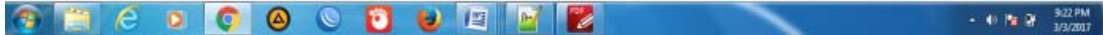

\section{Gambar 22. Tampilan Data Angsuran Pinjaman Anggota}

Pada halaman tampilan data angsuranpinjaman anggota ini menampilkan seluruh informasi data angsuranpinjaman anggota, informasi data angsuranpinjaman anggota yang di tampilkan telah terdekripsi ke bentuk aslinya sehinnga dapat dimengerti isinya.

Pengujian keamanan data pada sistem informasi koperasi RIAS dilakukan dengan metode Black Box Testing[11] yang merupakan proses pengujian yang fokus pada proses masukan dan keluaran pada saat sistem informasi dijalankan. Penggunaan metode Black Box Testing pada tahap ini karena bertujuan untuk mengetahui sejauh mana keamanan data program dapat memenuhi kebutuhan (requirement) yang disebutkan dalam analisis pengguna. Pada pengujian keamanan data pada sistem informasi koperasi RIAS ini dilakukan proses pengujian sebagai berikut:

1) Halaman data user, dilakukan proses pengujian antara lain dengan memasukkan data pada form tambah data user kemudian melihat isi data yang terenkripsi pada database serta melihat data yang terdekripsi pada tampil data $u$ ser 
2) Halaman data anggota, dilakukan proses pengujian antara lain dengan memasukkan data pada form tambah data anggota kemudian melihat isi data yang terenkripsi pada database serta melihat data yang terdekripsi pada tampil data anggota

3) Halaman data simpanan, dilakukan proses pengujian antara lain dengan memasukkan data pada form tambah data simpanan kemudian melihat isi data yang terenkripsi pada database serta melihat data yang terdekripsi pada tampil data simpanan

4) Halaman data pinjaman, dilakukan proses pengujian antara lain dengan memasukkan data pada form tambah data pinjaman kemudian melihat isi data yang terenkripsi pada database serta melihat data yang terdekripsi pada tampil data pinjaman

5) Halaman data layanan, dilakukan proses pengujian antara lain dengan memasukkan data pada form tambah data layanan kemudian melihat isi data yang terenkripsi pada database serta melihat data yang terdekripsi pada tampil data layanan.

6) Halaman data angsuran, dilakukan proses pengujian antara lain dengan memasukkan data pada form tambah data angsuran kemudian melihat isi data yang terenkripsi pada database serta melihat data yang terdekripsi pada tampil data angsuran.

Sistem informasi koperasi yang diusulkan pada makalah ini memiliki beberapa perbedaan dengan sistem informasi koperasi yang lain yang sudah pernah dibuat, di antaranya adalah sistem informasi simpan pinjam karyawan [12], sistem informasi koperasi simpan pinjam bahtera [13]. Sedangkan pada sistem informasi yang diusulkan, data yang disimpan didalam databaseadalah terenkripsi. Pada sistem informasi simpan pinjam karyawan dan sistem informasi koperasi simpan pinjam bahtera, semua data yang tersimpan di dalam database tidak terenkripsi atau dalam bentuk yang aslinya [12] [13].

\section{KESIMPULAN}

Berdasarkan keseluruhan pengujian yang telah dilaksanakan, data yang di inputkan pada sistem informasi [7] koperasi RIAS dan di simpan di dalam database berhasil di enkripsi sehingga tidak dapat dibaca dan dimengerti artinya. Sistem informasi koperasi RIAS juga telah berhasil mengembalikan data yang sebenarnya pada menu tampil data ataupun laporan.

Sistem-sistem yang dibangun sebelumnya hanya menyimpan data pada database dengan bentuk sesuai dengan apa yang diinput, sehingga orang yang melihat isi database tersebut dapat membaca dan mengerti artinya.

\section{DAFTAR PUSTAKA}

[1] Manku, Saikumar and Vasanth,K. 2015. "Blowfish Encryption Algorithm For Information Security." ARPN Journal of Engineering and Applied Sciences, vol. 10. no. 10, 4717 - 4719.

[2] Basri.2016. "Kriptografi Simetris Dan Asimetris Dalam Perspektif Keamanan Data Dan Kompleksitas Komputasi.” Jurnal Ilmiah Ilmu Komputer, vol. 2. no. 2, 17 - 23.

[3] Primartha, Rifkie. 2011. "Penerapan Enkripsi Dan Dekripsi File Menggunakan Algoritma Data Encryption Standard (DES).” Jurnal Sistem Informasi (JSI), vol. 3. no. 2, 371 - 387.

[4] Andriani, Anik. 2015. "Perancangan Sistem Informasi Deteksi Kegagalan Koperasi Di Tingkat Provinsi Berbasis Algoritma C4.5." J. Nas. Tek. Elektro Dan Teknol. Inf. JNTETI, vol. 4. no. 1, 25 31.

[5] Manuaba, Ida Bagus Verry Hendrawan, et al. 2012. " Evaluasi Keamanan Akses Jaringan Komputer Nirkabel (Kasus : Kantor Pusat Fakultas Teknik Universitas Gadjah Mada).” J. Nas. Tek. Elektro Dan Teknol. Inf. JNTETI, vol. 1, no. 1, 13 - 17.

[6] Kodarisman, Raden and Nugroho, Eko. 2013. "Evaluasi Penerapan Sistem Informasi Manajemen Kepegawaian (SIMPEG) di Pemerintah Kota Bogor.” J. Nas. Tek. Elektro Dan Teknol. Inf. JNTETI, vol. 2. no. $2,24-32$.

[7] Iskandar, Dadang and Insap Santosa, P.2013. "Sistem Informasi Gardu Induk dan Gardu Distribusi berbasis Web." J. Nas. Tek. Elektro Dan Teknol. Inf. JNTETI, vol. 2. no. 2, 33 - 37

[8] Novaliendry, Dony. 2011. "Multimedia Pembelajaran Bahasa Mandarin Dan Website Promosi," Jurnal Teknologi Informasi \& Pendidikan, vol. 3. no. 1, 122 - 139

[9] Rosmala, Dewi, et al. 2012. "Implementasi Aplikasi Website E-Commerce Batik Sunda Dengan Menggunakan Protokol Secure Socket Layer (Ssl).” Jurnal Informatika, vol. 3. no. 3, 58 - 67.

[10] Ali, Achmad Holil Noor and Hutagalung, Alexander Farady. 2013. "Rancang Bangun Sistem Informasi Manajemen Dealer, Studi Kasus PT Telkomsel," SISFO-Jurnal Sistem Informasi, vol. 2. no. 1, 23-28.

[11] A.S, Rosa, Salahuddin. (2014). Rekayasa Perangkat Lunak. Bandung Indonesia: Informatika. 
Jurnal SIMETRIS, Vol 8 No 1 April 2017

ISSN: 2252-4983

[12] Puspitasari, Diah.2015. "Rancang Bangun Sistem Informasi Koperasi Simpan Pinjam Karyawan Berbasis Web.” Jurnal Pilar Nus Mandiri, vol. xi. no. 2, 186 - 196.

[13] Wijaya, Kristanto. 2015. "Rancang Bangun Sistem Informasi Simpan Pinjam Pada Credit Union Koperasi Simpan Pinjam Bahtera Dengan Fitur Nilai Rekomendasi Pemberian Pinjaman Berbasis Fuzzy." Jurnal Sistem dan Teknologi Informasi. JustIN, vol. 2. no. 1, 1-6. 